\title{
PENGARUH SUMBER BAHAN ORGANIK YANG BERBEDA TERHADAP KUALITAS PEMBUATAN MIKROORGANISME LOKAL (MOL)
}

\author{
Julianus Jeksen $^{1}$, Charly Mutiara ${ }^{2}$ \\ Program Studi Agroteknologi, Fakultas Pertanian, Universitas Nusa Nipa ${ }^{1}$ \\ Jl. Kesehatan-Alok Timur, Sikka-Flores, NTT \\ Program Studi Agroteknologi, Fakultas Pertanian, Universitas Flores ${ }^{2}$ \\ Jl. Sam Ratulangi-Paupire, Ende-Flores, NTT \\ mutiaracharly@ymail.com
}

\begin{abstract}
ABSTRAK
This study aims to determine the content of microorganisms from local microorganisms and determine their quality. This research is a descriptive study, where the results of the analysis of microbial content are described by the standard microbial content in Local Microorganisms.

The results showed that Local Microorganisms from the leaves of Kirinyu, Gamal, Lamtoro and vegetables wastes contained Lactobacillus, Saccharomyces mushrooms, Actinomycetes fungi, and phosphate solvent bacteria (BPF). Local microorganisms from these materials have not been able to produce good quality because they are still lower than the minimum technical requirements based on Minister of Agriculture Regulation number 70 of 2011, while Saccharomyces mushroom microorganism content, $\mathrm{pH}$ and phosphate solvent bacteria (BPF) are in accordance with technical requirements all types of local microorganisms positively contain phosphate solvent bacteria (BPF).
\end{abstract}

Key words : Kirinyu, Gamal, Lamtoro, vegetable wastes, Mikroorganisme Lokal.

\section{LATAR BELAKANG}

Pupuk organik mempunyai kelebihan antara lain meningkatkan kesuburan sifat kimia, fisik, dan biologi tanah, serta mengandung zat pengatur tumbuh yang penting untuk pertumbuhan tanaman(Sutanto, 2002).Pupuk organik dapat dibuat sendiri dengan memanfaatkan mikroorganismemikroorganisme yang dikembangbiakan seperti pada EM-4 atau mikroorganisme lokal (MOL).

Larutan MOL adalah larutan hasil fermentasi yang berbahan dasar dari berbagai sumber daya yang tersedia setempat baik dari tumbuhan maupun hewan.Larutan MOL mengandung unsur hara makro, mikrodan mengandung mikroorganisme yang berpotensi sebagai perombak bahan organik, perangsang pertumbuhan, dan agen pengendali hama 
dan penyakit tanaman sehingga baik digunakan sebagai dekomposer, pupuk hayati, dan pestisida organik (Purwasasmita, 2009).

Faktor-faktor yang menentukan kualitas larutan MOL antara lain media fermentasi, kadar bahan baku atau substrat, bentuk dan sifat mikroorganisme yang aktif di dalam proses fermentasi, $\mathrm{pH}$, temperatur, lama fermentasi, dan rasio C/N larutan MOL (Suriawiria,1996; Hidayat, 2006).Kualitas MOL yang ditentukan oleh faktor-faktor tersebut adalah kandungan hara dan Mikroorganisme di dalamnya.Sumber bahan untuk pembuatan MOL sangat bervariasi seperti dari limbah pertanian dan non pertanian dengan karakteristik sifat fisik dan kandungan hara yang sangat beragam sehingga kualitas MOL yang dihasilkan juga bervariasi mutunya. Oleh karena itu pengaruhnya terhadap produktivitas tanah dan tanaman pada lahan kering dan lahan sawah juga bervariasi (Hidayat, 2006).

Mikroorganisme yang terdapat di dalam MOL mempunyai berbagai peran yang penting dalam mendukung keburan tanah. Mikroorganisme tersebut berperan dalam mengurai bahan organik menjadi unsur-unsur anorganik yang tersedia bagi tanaman dan melindungi tanaman dari bakteri yang merugikan (Hanafiah, 2010).Mikroorganisme tersebut adalah bakteri dan jamur, seperti Lactobacillus, Actinomycetes, pelarut Fosfat dan Saccharomyces.

Lactobacillus adalah genus bakteri gram-positif, anaerobik fakultatif atau mikroaerofilik. Genus bakteri ini membentuk sebagian besar dari kelompok bakteri asam laktat, dinamakan demikian karena kebanyakan anggotanya dapat mengubah laktosa dan gula lainnya menjadi asam laktat. Lactobacillus memproduksi asam laktat melalui proses glikolisis atau pemecahan glukosa. Lactaobaccilus juga dapat menghambat pertumbuhan bakteri-bakteri patogen, sehingga tanaman terlindungi. Proses ini merupakan proses fisiologis dari Lactobacillus yang menghasilkan metabolit sekunder yang dapat berfungsi sebagai antibakteri atau bacteriocin. Anti bakteri ini memerlukan media tumbuh yaitu glukosa (Kuneapah, 2008).

Saccharomyces merupakan genus khamir atau ragi atau yeast yang memiliki kemampuan mengubah glukosa menjadi alkohol dan $\mathrm{CO}_{2}$. Saccharomyces merupakan mikroorganisme bersel satu tidak berklorofil, termasuk kelompok Eumycetes.. Pertumbuhan Saccharomyces dipengaruhi oleh adanya penambahan nutrisi yaitu unsur $\mathrm{C}$ sebagai sumber carbon, unsur $\mathrm{N}$ yang diperoleh dari penambahan urea, ZA, amonium dan pepton, mineral dan vitamin.Suhu optimum untuk fermentasi antara $28-30$ ${ }^{\circ} \mathrm{C}$ (Wikipedia, 2014).

Actinomycetes adalah kelompok bakteriGram positif dengan nisbah $\mathrm{G} / \mathrm{C}$ yang tinggi. Bakteri ini pernah diklasifikasi sebagai fungi (jamur, Mycota) karena ada anggotanya yang membentuk berkas-berkas mirip hifa serta menghasilkan antibiotik. Pemberian pupuk kandang yang kaya selulosa akan 
meningkatkan populasi Aktinobakteri di tanah. Pemupukan amonium atau nitrat yang terus-menerus menekan populasi karena Aktinobakteri tidak suka $\mathrm{pH}$ di bawah 6; sebaliknya, pengapuran untuk menaikkan $\mathrm{pH}$ juga menaikkan populasinya (Wikipedia, 2014).

Bakteri pelarut fospat merupakan bakteri decomposer yang mengkonsumsi senyawa carbon sederhana, seperti eksudat akar dan sisa tanaman. Aktivitas bakteri pelarut posfat akan tinggi pada suhu $30^{\circ} \mathrm{C}-40^{\circ} \mathrm{C}$ (bakteri mesophiles) (Wikipedia, 2014; Ilham dkk, 2014).

Mikroba-mikroba yang ada di dalam MOL, mempunyai peran utama yakni mengurai bahan organik menjadi unsurunsur organik yang tersedia bagi tanaman.Sumber bahan organik dalam pembuatan MOL, dapat berasal dari daun Kirinyuh, Gamal, Lamtoro dan Limbah sayur. Kirinyu merupakan salah satu bahan yang dapat dimanfaatkan dalam pembuatan MOL. Secara total kandungan hara kirinyuh per hektar adalah 103,44 kg $\mathrm{N}, 15,17 \mathrm{~kg} \mathrm{P}, 80,94 \mathrm{~kg} \mathrm{~K}, 63,94 \mathrm{~kg} \mathrm{Ca}$ (Hidayat, 2000).

Daun gamal sangat baik jika dimanfaatkan sebagai bahan baku pembuatan MOL. Hal ini karena, tanaman gamal (Gliricidia sepium) merupakan salah satu jenis tanaman leguminosa dengan kandungan unsur hara yang tinggi. Gamal mengandung 3-6\% N; 0,31 $\% \mathrm{P} ; 0,77 \%$ K; $15-30 \%$ serat kasar (Purwanto, 2007).

Selain gamal dan kirinyuh, serasah lain yang dapat dimanfaatkan untuk pembuatan MOL adalah lamtoro. Hasil penelitian yang dilakukan Palimbungan dkk (2006), menyebutkan bahwa sebagai pupuk daun lamtoro mengandung 3,84\% $\mathrm{N}, 02 \% \mathrm{P}, 2,06 \% \mathrm{~K}, 1,31 \% \mathrm{Ca}$, dan $0,33 \% \mathrm{Mg}$. Dalam penelitian tersebut, dosis pupuk ekstrak lamtoro memberikan pertumbuhan dan hasil lamtoro yang optimal.

Dalam pembuatan MOL, perlu diketahui berbagai bahan yang memiliki kandungan hara yang berbeda, karena itu limbah sayur dianggap sebagai salah satu bahan yang cocok dalam pembuatan MOL. Berdasarkan hasil kajian secara laboratoris, pupuk organik cair yang berasal dari saripati limbah sayuran dan buah-buahan memenuhi syarat sebagai pupuk, baik sebagai sumber unsur makro maupun mikro. Hasil pengujian di lapangan menunjukkan bahwa pupuk organik cair berbahan baku saripati limbah sayuran dan buahan (Teknologi BPTP) memiliki kemampuan yang hampir sama dengan pupuk kandang 5 ton/ha + urea $10 \mathrm{~kg} / \mathrm{ha}$ (Badan LitBang Pertanian, 2007).

Berdasarkan uraian di atas, maka peneliti merasa tertarik untuk melakukan penelitian dengan judul "Pengaruh Sumber Bahan Organik Yang Berbeda Terhadap Kualitas Pembuatan Mol (Mikroorganisme Lokal)".

\section{METODE PENELITIAN}

\section{Tempat Dan Waktu}

Pembuatan MOL dilaksanakan di Kelurahan Lokoboko, Kecamatan Ndona, Kabupaten Ende. Sedangkan Analisis 


\begin{abstract}
Laboratorium dilaksankan di Laboratorium Fakultas Pertanian Universitas Brawijaya. Penelitian dilaksanakan selama 3 bulan.
\end{abstract}

\section{Alat Dan Bahan}

Bahan-bahan yang digunakan dalam penelitian ini adalah daun kerinyu, gamal, lamtoro, limbah sisa sayuran, kotoran ternak, dedak, gula pasir, air, air kelapa yang sudah tua, terasi sedangkan alat yang digunakan adalah ember dan parang.

\section{Metode}

Penelitian ini merupakan penelitian deskriptif, dimana data hasil analisis Laboratorium di deskrispikan berdasarkan peraturan menteri Pertanian Nomor 70 tahun 2011 tentang standar mutu pupuk organik.

\section{HASIL DAN PEMBAHASAN}

Pada Tabel 1. menunjukkan hasil analisis kimia larutan MOL dari berbagai sumber bahan organik sangat beragam berdasarkan sumber bahan organik yang digunakan.Pada perlakuan pembuatan MOL dari bahan daun kirinyu mendapatkan bakteri Lactobacillus sebesar $1,4.10^{5}$ CFU/ml, jamur Saccharomyces sebesar 1,7.10 ${ }^{3} \mathrm{CFU} / \mathrm{ml}$, Actinomycetes sebesar $3,0.10^{3} \mathrm{CFU} / \mathrm{ml}$ dan bakteri pelarut Fosfat sebesar 3,1.10 ${ }^{4}$ CFU/ml.Pada perlakuan pembuatan MOLdari bahan daun gamal mendapatkan bakteri Lactobacillus sebesar

\section{Pelaksanaan Penelitian}

Pelaksanaan penelitian dimulai dengan pembuatan mol dari daun kirinyu, gamal, lamtoro dan limbah sayuran., lalu mol yang telah jadi dianalisis di Laboratorium untuk mengetahui kandungan mikroorganisme di dalamnya.

\section{Variabel Pengamatan}

Variabel yang diamati meliputi
Lactobacillus,
Actinomycetes, dan Bakcharomyces,
Bakteri pelarut
fosfat.

Data hasil pengamatan yang diperoleh merupakan data hasil analisis laboratorium kemudian data dibandingkan dengan data Standart Nasional Indonesia tentang persyaratan teknis minimal pupuk hayati majemuk yang dikeluarkan melalui peraturan Meteri Pertanian No 70 Tahun 2011 dan selanjutnya data disajikan dalam bentuk tabel atau grafik.

7,7.10 $\mathrm{CFU} / \mathrm{ml}$, jamur Saccharomyces sebesar 4,2.10 $\mathrm{CFU} / \mathrm{ml}$, Actinomycetes sebesar $1,5.10^{3} \mathrm{CFU} / \mathrm{ml}$ dan bakteri pelarut Fosfat sebesar $1,0.10^{2} \quad$ CFU/ml.Pada perlakuan pembuatan MOL dari bahan daun lamtoro mendapatkan bakteri Lactobacillus sebesar $\quad 6,5.10^{3} \quad \mathrm{CFU} / \mathrm{ml}$, jamur Saccharomyces sebesar $3,9.10^{3}$ CFU/ml, Actinomycetes sebesar $4,8.10^{4} \mathrm{CFU} / \mathrm{ml}$ dan bakteri pelarut Fosfat sebesar 2,7.10 CFU/ml.Pada perlakuan pembuatan MOL dari bahan sisa sayuran sama sekali tidak memiliki kandungan bakteri Lactobacillus 
tetapi memiliki kandungan jamur bakteri pelarut Fosfat sebesar 1,1.10 Saccharomyces sebesar $3,0.10^{2} \mathrm{CFU} / \mathrm{ml}, \quad \mathrm{CFU} / \mathrm{ml}$. Actinomycetes sebesar $1,3.10^{3} \mathrm{CFU} / \mathrm{ml}$ dan

Tabel 1. Hasil Analisis Laboratorium Pembuatan Larutan Mikroorganisme Lokal (MOL) Dari Berbagai Sumber Bahan Organik Yang Berbeda.

\begin{tabular}{lcccc}
\hline \multirow{2}{*}{ Perlakuan } & \multicolumn{4}{c}{ Hasil Analisa : CFU/ml Sampel } \\
\cline { 2 - 5 } & Lacto & Sacch & Actino & P. Fosfat \\
\hline Daun Kirinyu & $1,4.10^{5}$ & $1,7.10^{3}$ & $3,0.10^{3}$ & $3,1.10^{4}$ \\
Daun Gamal & $7,7.10^{4}$ & $4,2.10^{4}$ & $1,5.10^{3}$ & $1,0.10^{2}$ \\
Daun Lamtoro & $6,5.10^{3}$ & $3,9.10^{3}$ & $4,8.10^{4}$ & $2,7.10^{4}$ \\
Sisa Sayuran & 0 & $3,0.10^{2}$ & $1,3.10^{3}$ & $1,1.10^{4}$ \\
\hline
\end{tabular}

\section{Lactobacillus dan Saccharomyces}

Lactobacillus berfungsi dalam melakukan fermentasi bahan organik (glukosa, pati, hemiselulosa) menjadi senyawa-senyawa asam organik yang mempunyai berat molekul rendah berupa asam laktat yang mudah diserap tanaman. Asam laktat yang dihasilkan merupakan hasil sterilisasi yang kuat yang dapat menekan mikroorganisme berbahaya (Rao, 2010).

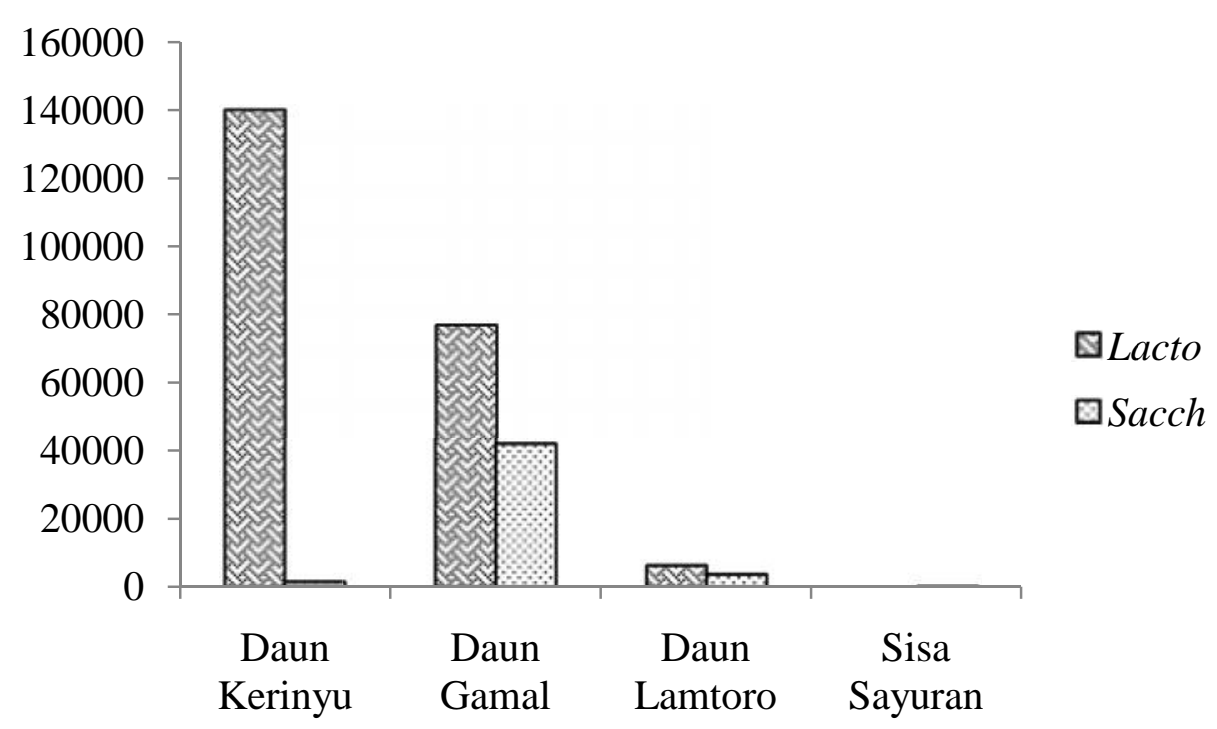

Gambar 1. Hasil Analisis Lactobacillus dan Saccharomyces 
Kandungan bakteri Lactobasillus tertinggi terdapat pada larutan MOL dari bahan organik daun gamal yaitu sebesar 7,7.10 4 CFU/ml, kemudian diikuti dengan larutan MOL dari bahan organik daun lamtoro sebesar $6,5.10^{3} \mathrm{CFU} / \mathrm{ml}$, larutan MOL dari bahan organik daun kirinyu sebesar $1,4.10^{5} \mathrm{CFU} / \mathrm{ml}$, lalu yang terakhir dan yang tidak mengandung bakteri Lactobacillus adalah larutan MOL dari bahan organik sisa sayuran. Hasil tersebut tidak sesuai dengan Peraturan Menteri Pertanian No. 70/ Permentan/ SR.140/ 10/ 2011 yaitu sebesar $\geq 10^{7}$ CFU/ml. Hasil ini masih kekurangan sebanyak $10^{3} \mathrm{CFU} / \mathrm{ml}$ agar mampu menyamai persyaratan teknis minimal kandungan Lactobacillus pada larutan MOL. Hal ini kemungkinan disebabkan oleh lamanya fermentasi, sumber MOL, kelembaban, aerasi, suhu, sumber energi (bahan organik), kemasaman $(\mathrm{pH})$, penambahan bahan inorganik dan komposisi yang digunakan dalam pembuatan larutan MOL (Suriawiria,1996; Hidayat, 2006). Hasil penelitian Seni dkk (2013) menunjukkan bahwa waktu fermentasi MOL sangat berpengaruh pada komposisi mikroorganisme yang hidup di dalam MOL tersebut.

Lactobacillus dapat mengakibatkan kemandulan (sterilizer) oleh karena itu bakteri ini dapat menekan pertumbuhan mikroorganisme yang merugikan; meningkatkan percepatan perombakan bahan organik; menghancurkan bahan organik seperti lignin dan selulosa serta memfermentasikannya tanpa menimbulkan senyawa beracun yang ditimbulkan dari pembusukan bahan organik. Bakteri ini dapat menekan pertumbuhan fusarium, yaitu mikroorganime merugikan yang menimbukan penyakit padalahan/ tanaman yang terus menerus ditanami (Widyastuti, dkk., 2009).

Bakteri Lactobacillus mampu menghasilkan antibiotik alami (zat) pembunuh bakteri pathogen (Anonim, 2010). Selama fermentasi, bakteri asam laktat ini tidak hanya berpengaruh terhadap makanan dan rasa tetapi juga memproduksi dan mengeluarkan senyawa antimikroba, seperti bakteriosin. Bakteriosin merupakan senyawa protein yang memiliki efek bakterisida terhadap mikroorganisme lain (Pal et al., 2005).

Melalui proses fermentasi, Saccharomyces menghasilkan senyawasenyawabermanfaat bagi pertumbuhan tanaman dari asam amino dan gula yang dikeluarkan oleh bakteri fotosintetik atau bahan organik dan akar-akar tanaman.Saccharomyces juga menghasilkan zat-zat bioaktif seperti hormon dan enzim untuk meningkatkan jumlah sel aktif dan perkembangan akar. Sekresi Saccharomyces adalah substrat yang baik bakteri asam laktat dan Actinomycetes (Wikipwedia Indonesia, 2014).

Berdasarkan hasil analisis laboratorium, kandungan jamur Saccharomycestertinggi terdapat pada larutan MOL dari bahan organik daun gamal yaitu sebesar 4,2.10 $\mathrm{CFU} / \mathrm{ml}$, kemudian diikuti dengan larutan MOL 
dari bahan organik daun lamtoro sebesar 3,9.10 $\mathrm{CFU} / \mathrm{ml}$, larutan MOL dari bahan organik sisa sayuran sebesar $3,0.10^{2}$ $\mathrm{CFU} / \mathrm{ml}$, lalu yang terakhir adalah larutan MOL dari bahan organik daun kirinyu sebesar $1,7.10^{3} \mathrm{CFU} / \mathrm{ml}$. Hasil tersebut sudah sesuai dengan Peraturan Menteri PertanianNo.

70/Permentan/SR.140/10/2011 untuk larutan MOL yaitu sebesar $\geq 10^{4} \mathrm{CFU} / \mathrm{ml}$. Hal ini disebabkan oleh media fermentasi, kadar bahan baku atau substrat, bentuk dan sifat mikroorganisme yang aktif didalam proses fermentasi, $\mathrm{pH}$, temperatur, lama fermentasi dan rasio $\mathrm{C} / \mathrm{N}$ larutan MOL sangat mendukung proses terbentuknya jamur Saccharomyces. Mikroorganisme memerlukan sumber karbon sebagai sumber energi dan perkembangbiakanya (Hidayat, 2006).

\section{Actinomycetes dan Bakteri Pelarut Fosfat}

Actinomycetes merupakan organisme peralihan antara bakteri dan jamur yang mengambil asam amino dan zat serupa yang diproduksi bakteri fotosintetik dan mengubahnya menjadi antibiotik untuk mengendalikan patogen, menekan jamur dan bakteri berbahaya dengan menghancurkan khitin (Indriani, 2011). Actinomycetes menghasilkan zat-zat anti mikroba dari asam amino yangdihasilkan bakteri fotosintetik. Zat-zat anti mikroba ini menekan pertumbuhanjamur dan bakteri. Actinomycetes hidup berdampingan dengan bakteri fotosintetikbersama-sama meningkatkan mutu lingkungan tanah dengan cara meningkatkanaktivitas anti mikroba tanah.

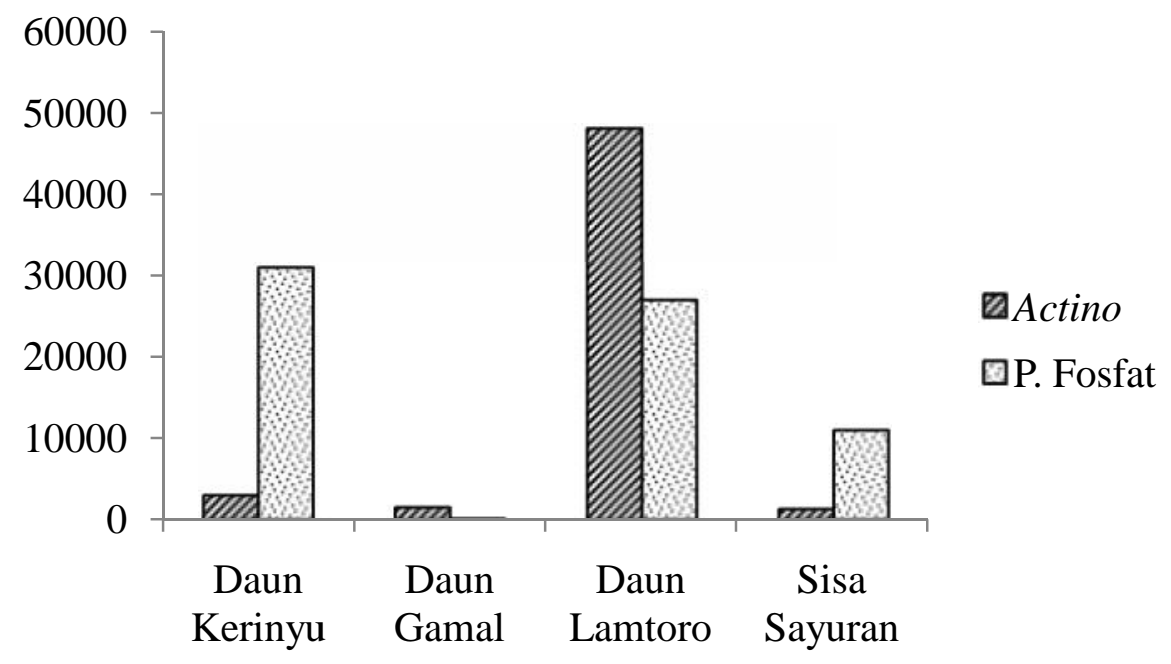

Gambar 2. Hasil Analisis Actinomycetes dan Bakteri Pelarut Fosfat

Kandungan jamur Actinomycetes tertinggi terdapat pada larutan MOL dari bahan organik daun lamtoro yaitu sebesar
4,8.10 $\mathrm{CFU} / \mathrm{ml}$, kemudian diikuti dengan larutan MOL dari bahan organik daun kirinyu sebesar $3,0.10^{3} \mathrm{CFU} / \mathrm{ml}$, lalu 
larutan MOL dari bahan organik daun gamal sebesar $1,5.10^{3} \mathrm{CFU} / \mathrm{ml}$ dan yang terakhir adalah larutan MOL dari bahan organik sisa sayuransebesar $1,3.10^{3}$ $\mathrm{CFU} / \mathrm{ml}$. Hasil tersebut tidak sesuai dengan Peraturan Menteri Pertanian No. 70/ Permentan/ SR.140/ 10/ 2011 yaitu sebesar $\geq 10^{6} \mathrm{CFU} / \mathrm{ml}$. Hasil ini masih kekurangan sebanyak $10^{2} \mathrm{CFU} / \mathrm{ml}$ agar mampu menyamai persyaratan teknis minimal kandungan Actinomycetes pada larutan MOL. Hal ini kemungkinan disebabkan oleh lamanya fermentasi, sumber MOL, kelembaban, aerasi, suhu, sumber energi (bahan organik), kemasaman $(\mathrm{pH})$, penambahan bahan inorganik dan komposisi yang digunakan dalam pembuatan larutan MOL(Suriawiria,1996; Hidayat, 2006).Komposisi mikroorganisme yang ada di dalam MOL bergantung dari lamanya fermentasi dan komposisi $\mathrm{C}$ organik di dalam MOL tersebut.Komposisi $\mathrm{C}$ organik ini berkaitan dengan sumber karbon bagi mikroorganisme tersebut (Seni dkk, 2013).

Salah satu alternatif untuk meningkatkan efisiensi pemupukan dalam mengatasi rendahnya fosfat tersedia dalam tanah adalah memanfaatkan kelompok mikroorganisme pelarut fosfat yang melarutkan fosfat tidak tersedia menjadi tersedia sehingga dapat diserap oleh tanaman. Pemanfaatan mikroorganisme pelarut fosfat dalam mengatasi masalah P pada tanah masam (Rao dan Sinha, 1963). Pelarutan secara biologis terjadi karena mikrooganisme tersebut memang menghasilkan enzim fosfatase yang merupakan enzim yang akan dihasilkan oleh ketersediaan fosfat rendah, proses mineralisasi bahan organik, senyawa diuraikan menjadi bentuk fosfat anorganik yang tersedia bagi tanaman dengan enzim fosfatase. Enzim fosfatase dapat memutuskan fosfat yang terikat oleh senyawa-senyawa organik dalam bentuk tersedia (Lynch, 1983). Fungsi pelarut $P$ meningkatkan kadar fosfat terlarut hingga $27-47 \%$ (Saraswati, dkk, 2006).

Berdasarkan hasil analisis laboratorium, kandungan bakteri pelarut fosfat (BPF) tertinggi terdapat pada larutan MOL dari bahan organik daun kirinyu yaitu sebesar $3,1.10^{4} \mathrm{CFU} / \mathrm{ml}$, kemudian diikuti dengan larutan MOL dari bahan organik daun lamtoro sebesar 2,7.10 $\mathrm{CFU} / \mathrm{ml}$, lalu larutan MOL dari bahan organik sisa sayuran sebesar $1,1.10^{4} \mathrm{CFU} / \mathrm{ml}$ dan yang terakhir adalah larutan MOL dari bahan organik daun gamal sebesar $11,0.10^{2} \mathrm{CFU} / \mathrm{ml}$. Hasil tersebut masih di bawah acuan komposisi bakteri tersebut, seperti yang tertuang dalam Peraturan Menteri PertanianNo. 70/Permentan/SR.140/10/2011. Hal ini disebabkan oleh media fermentasi, kadar bahan baku atau substrat, bentuk dan sifat mikroorganisme yang aktif didalam proses fermentasi, $\mathrm{pH}$, temperatur, lama fermentasi dan rasio $\mathrm{C} / \mathrm{N}$ larutan $\mathrm{MOL}$ sangat mendukung proses terbentuknya bakteri pelarut fosfat (BPF) (Suriawiria,1996; Hidayat, 2006). Bakteri pelarut fosfat (BPF) merupakan kelompok mikroorganisme tanah yang 
berkemampuan melarutkan $\mathrm{P}$ yang terfiksasi dalam tanah dan mengubahnya menjadi bentuk yang tersedia sehingga dapat diserap tanaman. Mikroorganisme pelarut fosfat ini dapat berupa bakteri (Pseudomonas, Bacillus, Escheria, Actinomycetes, dan lain lain). Mekanisme kerja BPF sehingga mampu melarutkan $\mathrm{P}$ tanah dan $\mathrm{P}$ asal pupuk yang diberikan diduga didasarkan pada sistem sekresi bakteri barupa asam organik, meningkatnya asam organik biasanya diikuti dengan pembentukan kelat dari $\mathrm{Ca}$ dengan asam organik tersebut sehingga $\mathrm{P}$ dapat larut dan $\mathrm{P}$ tersedia tanah meningkat (Ilham dkk, 2014).

Mekanisme pelarutan fosfat dari bahan yang sukar larut banyak dikaitkan dengan aktivitas mikroba yang mempunyai kemampuan menghasilkan enzim fosfatase, fitase, dan asam organik hasil metabolisme seperti asam asetat, propionat, glikolat, fumarat, oksalat, suksinat, tartrat, sitrat, laktat, dan ketoglutarat. Tetapi pelarutan $\mathrm{P}$ dapat pula dilakukan oleh mikroorganisme yang tidak menghasilkan asam organik, yaitu melalui: (1) mekanisme pelepasan proton (ion $\mathrm{H}+$ ) pada proses respirasi, (2) asimilasi amonium (NH4+), dan (3) adanya kompetisi antara anion organik dengan ortofosfat pada permukaan koloid yang dapat pula menyebabkan terjadinya movilizáis ortofosfat (Ilham dkk, 2014).

Menurut Narsian dan Patel (2000) pelarutan $\mathrm{P}$ oleh mikroorganisme pelarut fosfat selain terjadi karena proses kelasi dan reaksi pertukaran, juga disebabkan oleh menurunnya $\mathrm{pH}$ rizosfer akibat adanya asam oragnik. Sebelumnya Kirk (1999) berpendapat bahwa mekanisme utama agar tanaman dapat mengekstrak $\mathrm{P}$ dari sumber-sumber yang tidak dapat larut terjadi melalui: (1) produksi asam organik yang dapat menyebabkan $\mathrm{pH}$ rizosfer menurun (penurunan $\mathrm{pH}$ itu menjadi penting jika banyak asam organik yang diekskresikan), (2) produksi asam organik yang dapat berkompetisi dengan P pada tempat adsorpsi, dan (3) produksi asam organik dapat membentuk kompleks yang dapat larut dengan ion logam dan membebaskan P. Tan (1995) menyatakan bahwa selain enzim fosfatase yang dihasilkan oleh BPF yang dapat menghasilkan fosfat bebas, ada pula yaitu enzim fitase, firofosfatase, dan metafosfatase.

Lama proses fermentasi bahan-bahan MOL kurang lebih 10-15 hari (Santosa, 2008).Waktu fermentasi oleh MOL berbeda-beda antara satu jenis bahan MOL dengan yang lainnya. Waktu fermentasi ini berhubungan dengan ketersediaan makanan yang digunakan sebagai sumber energi dan metabolisme dari mikrobia didalamnya. Waktu fermentasi MOL yang paling optimal pada fermentasi hari ke-7 dan hari ke-14. Mikrobia pada MOL cenderung menurun setelah hari ke-7. Hal ini berhubungan dengan ketersediaan makanan dalam MOL. Semakin lama maka makanan akan berkurang karena dimanfaatkan oleh mikrobia di dalamnya (Suhastyo, 2011). Faktor-faktor yang mempengaruhi pertumbuhan mikrobia dan MOL adalah 
sumber MOL, kelembaban, aerasi, suhu, sumber energi (bahan organik), kemasaman $(\mathrm{pH})$ dan penambahan bahan inorganik. Sumber MOL juga menentukan jumlah mikrobia yang tumbuh karena sumber MOL sebagai bahan dasar penyedia bakteri yang akan ditumbuhkan (Suhastyo, 2011). Kelembaban yang sesuai dengan pertumbuhan bakteri adalah antara 60 $80 \%$. Aerasi bertujuan untuk memberikan kondisi yang baik untuk pertumbuhan mikrobia, yaitu untuk menyuplai gas $\mathrm{O}_{2}$ dan $\mathrm{CO}_{2}$ yang menentukan jenis mikrobia yang tumbuh aerob atau anaerob (Imas dan Setiadi, 1988). Suhu pertumbuhan bakteri adalah pada kisaran $15-45^{\circ} \mathrm{C}$, sedangkan pada suhu mesofil $\left(25-35^{\circ} \mathrm{C}\right)$ pertumbuhan paling banyak. Derajat keasaman $(\mathrm{pH})$ yang optimum pada pertumbuhan bakteri antara 6,5-7,5 (Rao, 2010).

\section{SIMPULAN}

1. Hasil penelitian menunjukkan bahwa pembuatan larutan MOL dengan menggunakan bahan organik daun kirinyu, gamal, lamtoro dan sisa sayuran mengandung bakteri Lactobacillus, jamur Saccharomyces, jamur Actinomycetes dan bakteri pelarut fosfat (BPF).

2. Pembuatan larutan MOL dengan menggunakan bahan organik daun kirinyu, gamal, lamtoro dan sisa sayuran belum mampu menghasilkan kualitas yang baik karena masih kurang dari persyaratan teknis minimal larutan MOL berdasarkan Peraturan
Menteri Pertanian No.70 tahun 2011, sedangkan kandungan mikroorganisme jamur Saccharomyces $\mathrm{pH}$ dan bakteri pelarut fosfat (BPF) saja yang sudah sesuai dengan persyaratan teknis minimal larutan MOL.

\section{UCAPAN TERIMA KASIH}

Pada kesempatan ini penulis ingin mengucapkan terima kasih kepada semua pihak yang telah membantu dengan caranya masing-masing dalam melengkapi tulisan ini

\section{DAFTAR PUSTAKA}

Anonim, 2010. http://forum .detik.com/Prospek Peluang Bisnis Asap Cair/Cuka Asap (Liquid Smoke). Diakses tanggal 4 November 2014.

Anonim. 2011. Pembuatan MOL (Mikroorganisme Lokal). http://id.shvoong.com.Diunduh 9 Desember 2014.

Badan LitBang Pertanian. 2007. Pemanfaatan Limbah Sayuran dan Buah-Buahan sebagai Pupuk Organik Cair dan Pakan Ternak. Kementrian Pertanian. Jakarta.

Darwis; Judoamidjoo, M.; Hartoto, L. 1992. Teknologi Fermentasi. Rajawali Press, Jakarta.

Dewi, K.A.C.J. 2012. Sifat Biologi Tanah Dan Mineralisasi Hara, N, P, K, Pada Beberapa Tipe Penggunaan Lahan Di Desa Pengeragoan Kecamatan Pekutatan Kabupaten Jembrana. Skripsi. Konsentrasi 
Ilmu Tanah dan Linggkungan, Jurusan/PS Agroekoteknologi,

Fakultas Pertanian, Universitas Udayana.

Hanafiah, K. A. 2005. Dasar-Dasar Ilmu Tanah. Rajawali Pers, Jakarta.

Harizena, I N. D. 2012. Pengaruh Jenis

Dan Dosis Mol Terhadap Kualitas

Kompos Sampah Rumah Tangga.

Skripsi. Konsentrasi Ilmu Tanah dan Lingkungan, Jurusan/Ps Agroekoteknologi, Fakultas Pertanian, Universitas Udayana.

Hardjowigeno, S. 2003. Ilmu Tanah.

Edisi Baru. Akademika Pressindo. Jakarta.

Hidayat, N. 2006. Mikrobiologi Industri. Andi offset, Yogyakarta.

Hidayat D. 2000.Pemanfaatan Kirinyuh

(Chromolena odorota) untuk media semai Gmelina arborea.Fakultas Kehutanan-Institut Pertanian Bogor. Bogor

http://edowartblogspotscom.blogspot.com /2011/10/pupuk-organik-cairmol.html

Ilham.,Darmayasa I.G.B.,Nurjaya

I.G.M.O.,Kawuri R. 2014. Isolasi dan Identifikasi Bakteri Pelarut Fosfat Potensial Pada Tanah Konvensial dan Tanah Organik.Jurnal Simbiosis. Vol. 2 (1): 173-183

Illmer, P. and F. Schinner. 1995. Solubilization of inorganic phosphate by microorganisms isolated from forest soils. Soil Biol. Biochem. 24(4): 389-395.
Illmer P.A., Barbato F, Schinner. 1995. Solubilization of hardlysoluable AlPO4 with P-solubilizing microorganism. Soil. Biol. Biochem. 27 (3): 265-270

Indriani, Y. H. 2011. Membuat Kompos Secara Kilat. Penebar Swadaya. Yogyakarta.

Kirk. 1999. Peranan Bahan Organik Terhadap Kesuburan Tanah Dan Upaya Pengelolaanya. Sebelas Maret University Press. Surakarta.

Lukitaningsih, D. 2010. Bioteknologi Mikroba Untuk Pertanian Organik. http:// luki2blog.wordpress.com/. Tanggal akses 29 Mei 2014.

Kuneapah U. 2008.Pengaruh Lama Fermentasi dan Konsentrasi Glukosa Terhadap Aktivitas Antibakteri, Polifenol Total dan Mutu Kimia Kefir Susu Kacang Merah.Program PascasarjanaUniversitas Diponegoro. Semarang

Lynch, J.M. 1983. Soil Biotechnology: Blackwell Sci. Pub. Co., London. $191 \mathrm{p}$.

Muriani, N. W. 2011. Pengaruh Konsentrasi Daun Gamal (Gliricidia Sepium) Dan Lama Fermentasi Terhadap Kualitas Larutan MOL. Skripsi. Program Studi Ilmu Tanah, Jurusan Agroekoteknologi, Fakultas Pertanian, Universitas Udayana.

Narsian dan Patel. 2000. Mikrobiologi Pangan. PT Gramedia Pustaka Utama, Jakarta.

Palimbungan N.,Labatar R.,Hamzah F. 2006. Pengaruh Ekstrak Daun Lamtoro Sebagai Pupuk Organik 
Cair Terhadap Pertumbuhan dan Produksi Tanaman Sawi.Jurnal Agrisistem. Vol. 2 (2): 96-101

Pal et al,.2005. Pemanfaatan Limbah Buah dalam Pembuatan MOL dengan Variasi Jenis Kemasan dan Lama Fermentasi. Skripsi Jurusan THP. Universitas Syiah Kuala, Banda Aceh.

Panudju, T. I. 2011. Pedoman Teknis Pengembangan Rumah Kompos Tahun Anggaran 2011. Direktorat Perluasan Dan Pengelolaan Lahan, Direktorat Jenderal Prasarana Dan Sarana Pertanian Kementerian Pertanian. Jakarta.

Parnata, A.S. 2004. Pupuk Organik Cair Aplikasi Dan Manfaatnya. Agromedia Pustaka. Jakarta.

Peraturan Menteri Pertanian No. 70/ Permentan/SR.140/10/2011.

Standar Mutu Pupuk Organik.

Prihandarini. 2004. Pengaruh Jenis Bahan Baku dan Lama Fermentasi terhadap Mutu MOL. Skripsi Jurusan THP. Universitas Syiah Kuala, Banda Aceh.

Purwanasasmita, M. 2009. Pemanfaatan Larutan Mol. http://riefarm.blogspot.com/. Tanggal aksess 2 Juni 2014.

Purwanasasmita. 2009b. Mikroorganisme Lokal Sebagai Pemicu Siklus Kehidupan Dalam Bioreaktor Tanaman. Makalah Seminar Teknik Kimia ITB 19-20 Oktober 2009, Bandung.

Purwanto. 2007. Pemanfaatan Daun Gamal Sebagai Larutan Mol. http://riefarm.blogspot.com/. Tanggal aksess 2 Juni 2014.

Rao, N.S. 1994. Mikroorganisme Tanah Dan Pertumbuhan Tanaman. Edisi Kedua. Jakarta: UI-Press.

Rao. N. S. S. 2010. Mikroorganisme Tanah Dan Pertumbuhan Tanaman. Edisi Kedua. Penerbit Universitas Indonesia. Jakarta.

Santoso, D. 1996. Pengaruh Penambahan Kompos Kirinyu (Chromolaena Odorata) Dan Gamal (Gliricidia sepium) Terhadap Serapan N Dan Hasil Sawi.Tesis. UniversitasPadjadjaran.

Santoso, D. 1998. Pengaruh Penambahan Kompos Kirinyu (Chromolaena odorata) Dan Gamal (Gliricidia sepium) Terhadap Serapan N Dan Hasil Sawi.Tesis. UniversitasPadjadjaran.

Santosa, E. 2008. Peranan Mikro Organisme Lokal Dalam Budidaya Tanaman Padi Metode Sysytem Of Rice Intensification. Departemen Pertanian, Jakarta.

Saraswati, dkk. 2006. Pertumbuhan Mikroorganisme. Universitas Negeri Malang, Malang.

Seni I.A.Y.,Atmaja i.W.D.,Sutari N.W.S. 2013. Analisis Kualitas Larutan MOL (Mikro Organisme Lokal) Berbasis Daun Gamal (Gliricidia Sepium).Jurnal Agroteknologi Tropika. Vol. 2 (2): 135-144

Sudjadi, M., I.M Widjik \& M. Soleh. 1971. Penuntun Analisis Tanah. Lembaga Penelitian Tanah Bogor, Bogor. 
Suhastyo, A. A. 2011. Studi Mikrobiologi dan Sifat Kimia Mikroorganisme Lokal yang Digunakan pada Budidaya Padi Metode SRI (System of Rice Intensification). Tesis. Sekolah Pascasarjana. Institut Pertanian Bogor. Bogor.

Sundara Rao, W. C. B and M. K. Sinha. 1963. Phospate dissolving microorganism in the soil and rhizosphere. Indian J. Sci. 23 : 272278.

Suriawiria, U.1996. Mikrobiologi Air. Penerbit alumni, Bandung.

Sutanto. 2002. Tingkat Kesuburan Tanah. http://.wordpress-kesuburan-tanah/. Tanggal Akses 15 Mei 2014.

Tan, K, H. 1993. Principles of Soil Chemistry : Genesis, Composition, Reaktion. John Willey \& Son. New York.

Tan, K. H. 1995. Degradasi Mineral Tanah oleh Asam Organik. UGM. Yogyakarta.
Widyastuti, R. R. 2009. Pemanfaatan Bonggol Pisang Raja Sere sebagai Bahan Baku Pembuatan Cuka. Sripsi S1. Universitas Muhammadiyah Surakarta. Surakarta.

Wikipedia. 2014. Bahan Organik Tanah. http: // id. wikipedia. Org /wiki/Bahan_organik_tanah.

Wikipedia. 2014. Saccharomyces cerevisiae. http: :/saccharomyces/Saccharomyces cerevisiae - Wikipedia bahasa Indonesia, ensiklopedia bebas.htm

Yusuf L.,Mulyati A.M.,Sanaba A.H. Pengaruh Dosis Pupuk Organik Padat Daun Gamal Terhadap Tanaman Sawi. Jurnal Agrisistem. Vol. 3 (2): 80-89

Peraturan Menteri Pertanian No. 70. 2011. Pupuk Organik, Pupuk Hayati dan Pembenah Tanah. 